\title{
On the Extrusion of the Nuclear Substance in Iris japonica, THUNB. ${ }^{1)}$
}

(Contributions from the Tokugawa Biological Institute, No. 3)

By

\section{Yosito Sinotô}

With 18 Text-Figures

The phenomenon of extrusion of the nuclear substance in prophase of pollen mother-cells into the cytoplasm of adjacent cells in Oenothera Lamarckiana, O. odorata, Portulaca glandiflora and Iris japonica was already mentioned briefly in my previous paper(22). The present results, of observations regarding the same phenomenon in Iris japonica have been obtained by the study of the specimens prepared for other purposes, so that the results may be far from being conclusive in ascertaining the cause or meaning of this phenomenon.

Young buds collected from the plants cultivated in a private garden were fixed either in Flemming's stronger solution or in Bonin's fluid; the stains used were HEIDENHaIN's iron-alum-haematoxylin with a counter-stain of light green, and the methylene blue-fuchsin combination; and the sections were cut 8 micra thick.

\section{OBSERVATIONS}

The fixation was generally bad for the study of meiotic phases. The extrusion seems to be more frequently observed in the materials fixed unsatisfactorily, not only in the case of the pollen mother-cells but also in that of the ovular- and ovarian cells. It is interesting to note that this phenomenon can often be found in the tapetal cells.

1) A somewhat detailed account was published in Japanese in this magazine, Vol. 35, No. 416, pp. (178)-(195), 1921. 
Pollen mother-cells:-When the extrusion occurs some nuclei occupy excentric positions in the cell, while others remain in the centre. This has been observed also by KöRNicke in Crocus vernus, ALL.(10). In Iris japonica the nuclear membranes are generally indistinct (Fig. 1), though at times something like a nuclear membrane or a blurred outline stained with methylene blue is observed.

The most active time for extrusion seems to be the synizetic stage as it has been pointed out by former investigators. But in presynizetic, spireme, hollow-spireme and even near diakinesis stages (Fig. 6) also the extrusion figures are found. The extrusion of the chromosomes or spindle fibers which is described by KöRNICKE was not observed in this plant. This may depend upon the time of separation of the mother-cells from each other.

It can not be said that all the extrusion from the mother-cells in a loculus of Iris japonica occurs in one direction only and simultaneously, though in certain mother-cells the extrusion seems to be in one and the same direction. The directions are generally manifold and the extrusions do not take place simultaneously. Cases are often observed where bodies extruded from one cell enter into two neighbouring cells, or bodies extruded from two cells enter into one, and sometimes a cell, receiving the materials extruded from two other cells, throws its nuclear substance into the next (Fig. 4).

Regarding the path of the extruded materials in the cell membrane Hottes in Vicia (9), Mrehe in Allium etc. (11), Körnicke in Crocus (10) and Schrammen in Vicia (15) lay stress upon the pores of plasmacontinuity (plasmodesm). DigBY (1), GATES (7) and WEST and LECHMERE (23) find respectively protoplasmic connections between the pollen mother-cells in Galtonia, Oenothera, and Lilium. The plasmodesms, or bundles of them, are also recognized in the favourable preparations of Iris japonica (Fig. 17) and it is most likely that the nuclear substance may pass through the pores of the plasmodesms or break through the pits into the cytoplasm of the adjoining cell. The connection between the extruded bodies and the nucleus from which they originate is sometimes one thick cord, or often one or more fine threads. It is not infrequently observed that each one of the small extruded bodies in one side of the cell has a slender connecting thread, while in other cases the nucleus is connected with one large extruded body by several fine threads.

The phenomena of passing of nuclear bodies from pollen mothercells into tapetal cells or the reverse can not be found in Iris japonica 
as it is in Oenothera (8), Lilium (23) etc, though the nuclear substance of the tapetal cell is occasionally extruded in the narrow space between the pollen mother-cell and the tapetum as seen in Fig. 7. This may probably depend on the absence or disappearance of the plasmodesms between them.

There are two views concerning the origin of extruded portions : i. that they originate in chromatin ${ }^{1)}$ only (Gates, WEST and LECHMERE); ii. that they originate in both chromatin and nucleolus (DIGBY). KöRNicke says that the nucleolus does not generally enter the neighbouring cell. In Iris japonica the second alternative appears to be the case (Fig. 5).

The shape of the extruded bodies is multifarious, and their number on one side of the cell is inconstant. For example, the shapes are globular, pear-shaped, rod-like, crescent, grape-like, irregularly massive, etc., and some, as described by DigBy and WEST and LECHMERE, protrude secondarily finger-like portions, while others show beaded, granular, or spireme-like appearances, the last being observed by Gates only in Oenothera. In Fig. 3 and Fig. 4 a part of some extruded bodies which is distant from the extrusion pore presents reticulate structures, and one long body penetrating a cell enters the next. The latter case is also shown in Fig. 15 which bears some resembrance to that of the vegetative cell in Iris germanica delineated by $\operatorname{SchüRHOFF(20).~Fig.~} 11$ shows a chromatin globule connected with its original mass by a long trailing tail coming into the central region of an adjacent mother-cell. The stage of nuclei in Fig. 6 is one preceding the diakinesis stage, in which the nuclear substance of a cell is not in the centre, and a part of it is extruded in the cytoplasm of the neighbouring cell, and takes an irregular massive form. In Fig. 16 which represents the material obtained from the same loculus as Fig. 6 two fine connections are seen between the extruded body and the main mass. In Fig. 2 a portion of chromatin goes into the cytoplasm progressing in the same direction as that of the contracting nuclear contents.

The nucleoli in this plant are in general globular even at the time of extrusion of the chromatin (Fig. 1, 2, 3, 5), though various other shapes are also found. Some of the nucleoli in Fig. 3 and Fig. 4 seem to be pinned against the cell wall and to take a semi-

1) In this paper hereafter the word chromatin means any nuclear substance except nucleolus. 
spherical form. In other cases there are seen nucleoli which are in the sickle-stage whose nature has been discussed by many authors, some explaining it as a normal phenomenon, while others attributing it to some artificial influence. ScHAFFNER attributes this stage to the action of the killing fluids $(16,18)$. The nucleoli of Iris japonica actively throw off many small bodies and seem to partake in extrusion as in the case of Galtonia described by DiGBy. It is unknown, however, whether the nucleolus moves into the adjacent cell without changing its form, or either after dividing into several small bodies or by the amoeboid movement. But the facts are that the small round bodies stained intensely or faintly with haematoxylin are found in the extruded substances as well as in the nuclear cavity of the cell in which the extrusion is observed (Fig. 5, 9), and that a large body resembling true nucleolus in shape and size is seen close to the chromatin extruded in the cytoplasm of a cell whose nucleus retains its normal condition (Fig. 5). A substance is seen to flow out of a nucleolus which is stained red by fuchsin and is pressing against the cell wall; and pass through the cell wall into the blue-stained chromatin which after being extruded into the adjoining cell remains close to the cell wall at a position opposite to the above-mentioned nucleolus. It is probable that in the manner stated above the nucleolar substance may flow into cytoplasm of the adjacent cell and become round. Whether many small bodies originate from the chromatin or from the nucleolus, it is still unknown, for it is difficult to ascertain the exact process either morphologically or by staining reaction (cf. 11, 15, 20). Concerning the position of the nucleolus there are two cases: $i$. the nucleolus in company with the chromatin it progresses to a position near the cell wall at the time of extrusion, ii. the nucleolus remains in the central region of the cell, while the chromatin moves towards the cell wall (Fig. 11). In some cases the nucleolus breaks into fragments. (Fig. 10) and in other cases they can not be discerned as shown in Fig. 8.

The clear area in the cytoplasm round the extruded portions was described by the above-mentioned authors. The conditions in Iris japonica in this respect are obvious in the cases shown in Figs. $1,3,4,9,15$ and 18 .

In my preparations of Iris, most of the pollen mother-cells show conspicuous plasmolysis and the cytoplasm is generally vacuolated, while there are found some mother-cells in which the cytoplasm is apparently normal as seen in Fig. 1 . In the former case the extrusion 


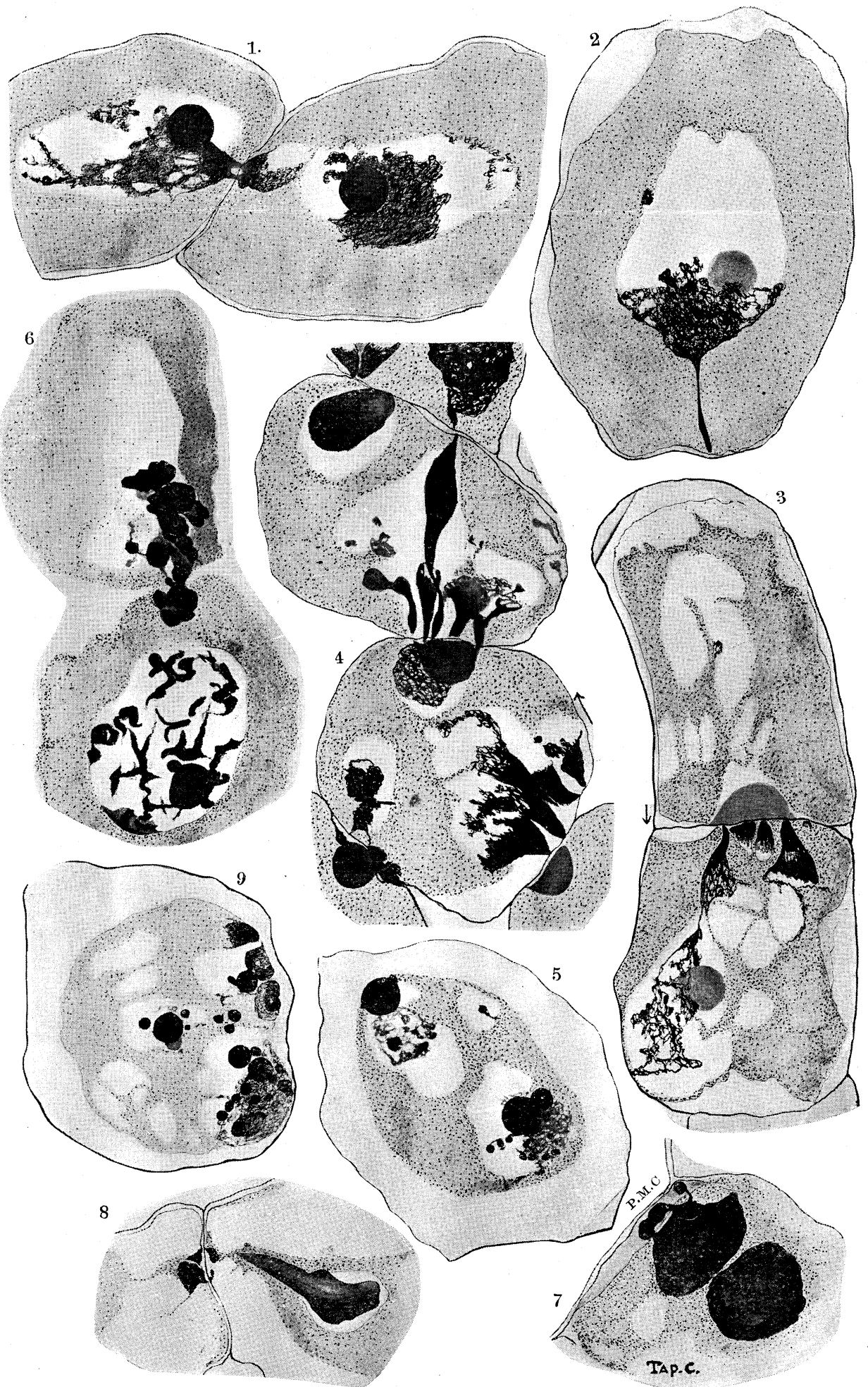


[Vol. XXXVI. No. 429.

figures are clearly observed, but not so in the latter. In the greater part of preparations the whole appearance of the pollen mother-cells found in the sections of the loculi suggests the probability that the cytoplasm and other ingredients of the pollen mother-cells have been damaged by some external injuries.

With regard to the fate of the extruded materials the descriptions by DigBY (1) and Gates (8) are at some length. They observe various features of the extruded bodies according to the stages of nuclear division, and they seem to explain these features as a continuous process. In Iris japonica various changes in the extruded portions are also to be seen, but I rather think that those changes should not be interpreted as a continuous process. This will be stated later.

Embryosac mother-cells:-The brief description that DigBY (1) has given with regard to Galtonia candicans appears to be the only instance, so far as I know, of this phenomenon in the embryosac mother-cells. In Iris japonica fragments of chromatin or small buds thrown off from the nucleolus are often found in the nuclear cavity, although the extrusion of the nuclear substance from the embryosac mother-cell into the cytoplasm of the adjoining nucellar cells fails to be observed. A large cell represented in the centre of Fig. 14 is an embryosac mother-cell whose nucleus is in the condition of synizesis, the synizetic ball with a nucleolus being apparently pressed against one side of the cell membrane.

Somatic cells :-The extrusion phenomena of the nuclear substance in the somatic cells as due to the action of temperature or injury by cutting or stripping were reported by several authors $(9,10,11,15,20)$. However in the tapetal-, integumental-, nucellar cells and the wall cells of ovary of Iris japonica which were not acted upon by high or low temperature nor injured by the section knife etc. the extrusions are not infrequently observed. Fig. 13 indicates a case in the wall cell of the ovary.

Tapetal cells :-The tapetal cells in Iris japonica include generally two nuclei at the time of the synizesis stage of pollen mother-cells. The extrusion in the tapetum is observed during the stages from synizesis to tetrad formation of the pollen mother-cells. In some cases the nuclei retaining their original features protrude a small portion of their substance by means of a fine connection, while in others the nuclear substance of one cell shows an appearance as if it penetrated like a ribbon through several other cells generally along the long 
axis of an anther (Fig. 12). It happens frequently that the nuclei of two, three, or sometimes more, cells unite with each other and then take a form as described in the last case. In some cases the connection between the extruded portion and the nucleus from which the former was derived, is kept not by fine thread, but by thick rods or bands which appear not to have crept out through the small pore in the membrane. In Fig. 18 along the protruded portion the cell membrane is seen as if it were pushed. From these facts it is suggested that the extrusion phenomena are not caused by the autonomy of the nucleus concerned, but is the result of mechanical injuries caused by some external action when the nucleus is in a particular physiological condition.

\section{GENERAL CONSIDERATION}

The extrusion of the nuclear substance in Iris japonica can not probably be attributed to the traumatic effect of cutting or stripping as in the cases of MiEHE and others $(11,15,20)$. In the present case the whole flower-buds with young stamens, pistil and perianth were immersed in a fixative with care so as not to give them any direct injury by the knife. KöRnICKe says that extrusion is found in the neighbourhood of the section of the filament in Crocus, but that in the anther there is no extrusion, while on the other hand it is observed in the anther fixed without being separated from the whole flower-bud.

The influence of temperature is here out of the question, for the materials were collected from the plants grown in a garden and not acted upon by any unusual temperature.

The external pressure, for example the pressure of the pincette, to which the materials were subjected at the time of fixation is thought possibly as a part of the cause of the extrusion; for when the flower-buds were brought into the fixing fluids by the aid of pincette, a good many extrusion figures were observed; while at the second fixing, when the peduncles of the flower-buds were cut by the knife before they were dropped into the fluid, there appeared probably less figures of extrusion than at the first time.

The interpretation of this phenomenon as the incidence of the subsequent degeneration of the mother-cell $(3,5,6)$, though it is an interesting suggestion, appears not to be convincing in my case of Iris japonica.

KöRNICKE's interpreting regarding this process in Crocus does 
not seem to be applicable to the case of Iris, for the condition of its anther in the bud at the time of fixation is quite different from that of Crocus.

Körnicke in Crocus (10), Digby in Galtonia, Primula and Crepis $(1,2,3,4)$, Gates in Oenothera (8), West and Lechmere in Lilium (23) etc. are not inclined to ascribe the extrusion phenomenon to any faulty fixation, but all except KörNICKE seem to be of opinion that it is normal in the meiotic course, while there are a number of investigators as Rosenberg $(13,14)$ in Crepis and Drosera, NakaO (12) in Cecale, Sakamura (21) in Vicia, Yasui (24) in Papaver etc. who attribute this extrusion phenomenon wholly or in part to the artifact due to the bad fixing.

The whole findings concerning to this process in my Iris japonica point to support the latter opinion. In Iris japonica the direction of extrusion in the loculus is not generally the same as it is in Crocus, Oenothera, Lilium etc. and the extrusion and the deformation of nucleus seem to occur oftener in the materials faultily fixed as stated above. DAvis says on one occasion that in Oenothera the fixing fluid enters the anther at the extremity; this may serve to explain the same direction of extrusion in Oenothera gigas etc. WEsT and LECHMERE inform that in Lilium 'a few loculi were noticed in which the mother-cells at either end were discharging toward the centre, whilst the cells occupying a position near the centre of the loculus retained the typical condition of complete synapsis.' This also seems to indicate the relation between the fixing fluid and the direction of extrusion. Concerning the cause of the change in the direction of extrusion I am not yet in a position to express any decisive view whether it is due to some modifying influence working upon the one definite direction which was given in the penetration of the fixing liquid into the terminal point of the anther, or whether it is to be attributed to the rapid penetration of the strong fixing fluid into various parts of the anther. When the disturbing action is strong it may extend even to the tapetum. I stated in another place (22) that the extrusion phenomena in Oenothera Lamarckiana were observed more frequently in the materials fixed with Bours's fluid, stronger Flemming's solution etc. than in those fixed with chrom-acetic solution, medium chrom-acetic solution etc. In two anthers of Lilium candidum fixed with Herman's solution, according to WEST and LECHMERE, the remarkable extrusion figures were observed (23).

That the nucleus attains a further development after only a 
small part of it is extruded is a possible interpretation, but it seems hard to account for the fact that such figures, for instance Fig. 4 and Fig. 5, in which the greater part of nuclear substances are extruded or even the nuclei are considerably deformed, are the normal phases of the cell phenomena. When the cells of ovary wall, nucellus and loculus are examined with care, it is often found that the nucleus alone or the whole contents of the cell lie excentrically in the cell, as if they were forced to do so by some external agent, but the extrusion phenomena are seldom observed, a fact which shrows that extrusion occurs with difficulty in the somatic cells. This may probably suggest the lack of extrusion between the embryosac mother-cell and the cells which compactly surround it. The inconspicuous plasma-connection between them will also help the suggestion. In the pollen- and embryosac mother-cells with the nuclei in the metaphasic stage, the plasmolysis and the chromosomes lumped in a mass are very often found. And such lumps are sometimes pressed towards one side of the cell. This may be caused by a faulty fixation. An extremely contracted state of the contents of the mother-cell nuclei is frequently observed, which seems to point to the opinion of SchafFner and others that synizesis is an artifact $(17,18,19)$. From the observations in Iris japonica it seems that the effect, direct or indirect, of the fixing fluid is one of the main categories of the external injuries. Various appearances of the extruded bodies in various stages of the dividing nucleus, which are viewed by DigBX, Gates and others as a continuous process, may probably be interpreted as various effects of the fixatives. And if this phenomenon be an artifact caused by the faulty fixation or some other external influence it will not have any importance on the heredity, the life-cycle, or the individuality of chromosomes, and probably it can not be considered as a normal phase in meiotic stages.

Lastly a few words will be added regarding synizesis and the extrusion. In the pollen mother-cells of Iris japonica there are cases where the synizetic mass can easily be recognized, while in others owing to the extreme deformation of the nucleus, it is not recognized. In the former cases it is of interest that the direction of the contraction of the nuclear contents appears to coincide with that of the extrusion of the same nucleus, and that the nucleus itself seems to be obliged to extrude its part by certain external force rather than by its autonomy. 


\section{SUMMARY}

1. An extrusion phenomenon of the nuclear substance in Iris japonica is described. The figures of extrusion from one cell into the cytoplasm of adjacent cells are found in pollen mother-cells as well as in tapetal-, integumental-, nucellar- and ovarian cells.

2. The extrusion in the pollen mother-cells is observed to be most active in the synizetic stage and occurs not infrequently in the presynizetic, spireme and hollow-spireme stages and sometimes immediately before the diakinesis stage. In somatic cells this process is generally found in the nuclei which are not in division.

3. The portions of the nucleus which are extruded may be chromatin, synizetic mass, spireme, nucleolus etc.

4. So far as the observation goes, I am inclined to side with the opinion that this phenomenon is chiefly caused by the fixing fluids and external injuries inflicted by pressure.

It is with pleasure that I take this occasion to express my sincere thanks to Marquis Yoshichika Tokugawa, the director of the Tokugawa Biological Institute, for all the facilities kindly offered throughout the course of this observation; my best thanks are also due to Professor FujII of the Botanical Institute, Science College, Tokyo Imperial University for his kind advice and valuable suggestion. I am much indebted to Viscount TAdamasa Miduno for his kindness in providing the materials used.

August 1921. The Tokugawa Biological Institute.

\section{LITERATURE CITED}

1. Digby, L. (1909). Observations on 'chromatin bodies' and their relation to the nucleolus in Galtonia candicans, DcNe. Ann. of Bot. 23 : 491-502.

2. (1910). The somatic, premeiotic, and meiotic nuclear divisions of Galtonia candicans. Ib. 24 : 727-757.

3. - (1912). The cytology of Primula Kevensis and of other related Primula Hybrids. Ib. 26 : 357-388.

4. -(1914). A critical study of the cytology of Crepis virens. Arch. f. Zellforsch. 12: $9^{-}-146$.

5. FrASER, H. C. I. (1914). The behavior of the chromatin in the meiotic divisions of Vicia Faba. Ann. of Bot. 28 : 633-642.

6. Gregory, R. P. (1905). The abortive development of the pollen in certain sweet peas. Proc. Cambr. phil. soc. 13 : 148-157. 
7. Gates, R. R. (1908). A study of reduction in Oenothera rubrinervis. Bot. Gaz. $46: 1-34$.

8. (1911). Pollen formation in Oenothera gigas. Ann. of Bot. 25 : 909-940.

9. Hоттеs, Сн. F. (1901). Ueber den Einfluss von Druckwirkungen auf die Wurzel von Vicia Faba. Inaugural-dissertation, Bonn. Cited after Schrammen (15).

10. KöRNicKe, M. (1901). Ueber Ortsveränderung von Zellkernen. Sitzungsber. d. niederrhein. Gesells. f. Natur-und Heilkunde z. Bonn, 1901: 14-25.

11. Mishe, H. (1901). Ueber Wanderungen des pflanzlichen Zellkerns. Flora 88 : 105-142.

12. NakaO, M. (1911). Cytological studies on the nuclear division of the pollen mother-cells of some cereals and their hybrids. Jour. Coll. Agr. Tohoku Imp. Univ. 4 : 173-190.

13. Rosenberg, O. (1909). Zur Kenntnes von den Tetradenteilung der kompositen. Sv. Bot. Tids. 3 : $64-77$.

11. (1909). Cytologische und morphologische Studien an Drosera longifolia $\times$ rotundifolia. Kungl. Sv. Vet. Akad. Handl. 43: 1-64. Cited after NAKAo (12).

15. Schrammen, J. R. (1902). Ueber die Einwirkung von Temperaturen auf die Zellen des Vegetationspunktes des Sprosses von Vicia Faba. Verhandl. d. naturhist. Vereins d. preuss. Rheinl. 59 : 4 - -98.

16. Schaffner, J. H. (1899). Artificial production of the sickle stage of the nucleolus. Jour. App. Micr. 2 : 321-322.

17. - (1906). Chromosome reduction in the microsporocytes of Lilium Tigrinum. Bot. Gaz. 41 : 183-191.

18. (1907). Synapsis and Synizesis. Ohio Nat. $7: 41-48$.

19. (1909). The reduction divisions in the microsporocytes of Agave virginica. Bot. Gaz. 47 : $198-214$.

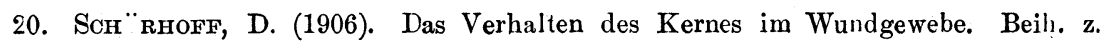
bot. Centralbl. 19 : 359-382.

21. Sakamura, T. (1920). Experimentelle Studien über die zell-und Kernteilung mit besonderer Rücksicht auf Form, Grösse und Zahl der Chromosomen. Jour. Coll. Sci. Imp. Univ. Tokyo 39, Art. 11.

22. Sinotô, Y. (1920). On the nuclear divisions and the partial sterility of Oenothera Lamarckiana, SER. (Japanese). Bot. Mag. Tokyo 34 : (277)-(292), (301)-(317).

23. WeSt, C. and LechmeRe, A. E. (1915). On chromatin extrusion in pollen mother-cells of Lilium cädidum, LINN. Ann. of Bot. 29 : 285-291.

24. YASUI, K. (1921). On the behavior of chromosomes in the meiotic phase of some artificially raised Papaver hybrids. (Japanese). Bot. Mag. Tokyo 35 : (167)-(178). 